\title{
ROCKET PRODUCTION IN A LOW COST HYDROPONIC SYSTEM USING BRACKISH WATER ${ }^{1}$
}

\author{
JOSÉ EUSTÁQUIO CAMPOS JÚNIOR ${ }^{2}$, JOSÉ AMILTON SANTOS JÚNIOR ${ }^{2}$, JULIANA BEZERRA MARTINS ${ }^{2 *}$, \\ ÊNIO FARIAS DE FRANÇA E SILVA², CERES DUARTE GUEDES CABRAL DE ALMEIDA ${ }^{3}$
}

\begin{abstract}
The production of vegetables in communities of family farmers in semiarid regions is limited due to rudimentary cultivation practices and systems, water scarcity, and excess salts in the water and soil. Thus, the objective of this work was to evaluate the production of rocket (Eruca sativa L. cv. Folha Larga) in a low cost hydroponic system, considering strategies for the use of brackish water in the nutrient solution. The experiments were conducted in complete randomized designs, in $6 \times 2$ factorial arrangements, with five replications, using rocket plants grown in different nutrient solutions, consisting of six salinity levels (1.5, 3.0, $4.5,6.0,7.5$, and $9.0 \mathrm{dS} \mathrm{m}^{-1}$ ) and two circulation frequencies of the nutrient solution (twice a day, at 8:00h, and 16:00h; and three times a day, at 8:00h, 12:00h, and 16:00h). In Experiment I, the nutrient solution lost by evapotranspiration was replenished with the respective brackish water used in its preparation; and in Experiment II it was replenished with public water $\left(0.12 \mathrm{dS} \mathrm{m}^{-1}\right)$. The shoot and root fresh and dry biomass of the plants and their respective dry weight proportions, and biometric variables were evaluated. Replenishing of the nutrient solution with public water resulted in lower losses in biomass and plant growth. The increases in circulation frequency of the nutrient solution did not affect the biometric variables, however, the plants prioritized shoot biomass development to the detriment of the root when using high circulation frequencies.
\end{abstract}

Keywords: Eruca sativa L.. Salinity. Cultivation without soil.

\section{PRODUÇÃO DE RÚCULA EM HIDROPONIA DE BAIXO CUSTO SOB ESTRATÉGIAS DE USO DE ÁGUAS SALINAS}

RESUMO - A produção de hortaliças em comunidades de agricultores familiares, residentes em condições semiáridas, são limitadas por práticas e sistemas rudimentares de cultivo, escassez hídrica e problemas de salinidade. Neste sentido, o objetivo do presente trabalho foi analisar a produção de rúcula, cv. Folha larga, em sistema de hidroponia de baixo custo, adotando-se estratégias de uso da água salina no preparo e reposição da solução nutritiva evapotranspirada. Em dois experimentos, plantas de rúcula foram expostas a seis níveis de salinidade da solução nutritiva $\left(1,5 ; 3,0 ; 4,5 ; 6,0 ; 7,5\right.$ e $\left.9,0 \mathrm{dS} \mathrm{m}^{-1}\right)$ aplicadas em duas frequências de circulação (duas vezes ao dia - às 8 e 16 horas; três vezes ao dia - às 8,12 e 16 horas). O delineamento experimental adotado foi inteiramente casualizado, em esquema fatorial $6 \times 2$, com cinco repetições, sendo que, no Experimento I a reposição da solução nutritiva foi efetuada com a respectiva água salina utilizada no preparo da solução e, no Experimento II, com água de abastecimento $\left(0,12 \mathrm{dS} \mathrm{m}{ }^{-1}\right)$. Analisou-se a fitomassa fresca e seca da planta, da parte aérea e da raiz, bem como as respectivas partições de matéria seca e variáveis biométricas. A reposição da lâmina evapotranspirada com água de abastecimento resultou em menores perdas de biomassa e no crescimento das plantas e que, o aumento da frequência de circulação não influenciou as variáveis biométricas, no entanto, sob maior frequência de circulação a planta priorizou o desenvolvimento da biomassa da parte aérea em detrimento da raiz.

Palavras-chave: Eruca sativa L.. Salinidade. Cultivo sem solo.

\footnotetext{
${ }^{*}$ Corresponding author

${ }^{1}$ Received for publication in $08 / 22 / 2017$; accepted in $05 / 02 / 2018$.

Paper extracted from the master dissertation of the first author.

${ }^{2}$ Department of Agricultural Engineering, Universidade Federal Rural de Pernambuco, Recife, PE, Brazil; camposjr.agro@gmail.com ORCID: 0000-0002-7720-2773, eng.amiltonjr@hotmail.com - ORCID: 0000-0002-1656-7103, julianaabmartins@gmail.com - ORCID: 0000-0002-9433-3230, enio.fsilva@ufrpe.br - ORCID: 0000-0002-8652-503X.

${ }^{3}$ Agricultural College Dom Agostinho Ikas, Universidade Federal Rural de Pernambuco, São Lourenço da Mata, PE, Brazil; ceres.codai.ufrpe@gmail.com - ORCID: 0000-0001-6073-3853.
} 


\section{INTRODUCTION}

The Brazilian semiarid region has low and irregular precipitation, and high evapotranspiration rate, which result in a negative water balance. In addition, its soils have predominance of crystalline rocks, which generate high salt rates in the available water, especially in subsoil waters (SANTOS et al., 2010; SOARES et al., 2010), increasing limitations for family farmers in diffuse communities, especially the vulnerability of agricultural production to salinity problems.

Studies have confirmed deleterious effects caused by salinity on plants (LIMA et al., 2014; LIMA et al., 2015; NASCIMENTO et al., 2015) that decrease or make unfeasible agricultural production, especially when using brackish water without technical monitoring and compatible technologies.

Therefore, development and adaptation of compatible technologies with this local reality are needed. Several studies report the use of hydroponic systems as an alternative for this problem, since they allow the use of brackish water in the nutrient solution, require small areas for implementation, and present several other advantages (SANTOS JÚNIOR et al., 2014; SANTOS JÚNIOR et al., 2015; SILVA et al., 2016; NUNES et al., 2013; SANTOS et al., 2016).

These benefits are due to the energy reordering caused by the minimization of the water matrix potential, making the energy required for water absorption by the plant reduce, practically, to the osmotic potential (SANTOS JÚNIOR et al., 2016). Moreover, proper management strategies for the preparation of nutrient solutions using brackish water can mitigate the effect of salinity on plants; and increasing the circulation frequency of the nutrient solution can provide greater oxygenation and solubilization of its nutrients (SOARES et al., 2010).

Coriander, lettuce, sweet pepper, and rocket are among the main cultivated vegetables in the Brazilian semiarid region (OLIVEIRA et al., 2012). These vegetables have been gaining ground in the market (COSTA et al., 2011), mainly because the use of their leaves in salads is very appreciated (SILVA; SILVA; KOLLESKA, 2016). Rocket is moderately tolerant to salinity (SILVA et al., 2013), and several studies report the hydroponic growth of rocket with the use of brackish waters (OLIVEIRA et al., 2012; SANTOS et al., 2012; SILVA et al., 2012), however, studies on strategies for the use of brackish water in rocket cultivation, especially regarding the preparation and replenishing of the nutrient solution, are still insipient.

The use of hydroponic systems for vegetable production, an expressive economic activity for family agriculture (MENEGAES et al., 2015; PANTOJA NETO et al., 2016), can increase plant production and generate employment and income (LEITE et al., 2016). Thus, the objective of this work was to evaluate the growth and production of rocket (Eruca sativa L. cv. Folha Larga) in a low cost hydroponic system, considering strategies for the use of brackish water in the nutrient solution.

\section{MATERIAL AND METHODS}

Two experiments were conducted in a greenhouse of the Agricultural Engineering Department of the Federal Rural University of Pernambuco, in Recife PE, Brazil ( $8^{\circ} 01^{\prime} 05^{\prime \prime} \mathrm{S}$; $35^{\circ} 56^{\prime} 48^{\prime \prime} \mathrm{W}$; and mean altitude of $6.49 \mathrm{~m}$ ) in September to December, 2016. According to the Köppen classification, the climate of this region is As, with annual average precipitation of $1,501 \mathrm{~mm}$, average temperature of $26^{\circ} \mathrm{C}$, and relative humidity of $76 \%$.

The experiments were conducted in complete randomized designs, in $6 \times 2$ factorial arrangements, with five replications, using rocket plants grown in different nutrient solutions, consisting of six salinity levels $\left(1.5,3.0,4.5,6.0,7.5\right.$, and $\left.9.0 \mathrm{dS} \mathrm{m}^{-1}\right)$ and two circulation frequencies of the nutrient solution (twice a day, at 8:00h and 16:00h; and three times a day, at 8:00h, 12:00h and 16:00h). In Experiment I, the nutrient solution lost by evapotranspiration was replenished with the respective brackish water used in its preparation; and in Experiment II it was replenished with public water $\left(0.12 \mathrm{dS} \mathrm{m}^{-1}\right)$.

The nutrient solution was prepared in twelve tanks filled with $90 \mathrm{~L}$ of public water; the amount of $\mathrm{NaCl}$ solubilized to reach the salinity rates was calculated based on the empirical equation of Richards (1954); and the fertilizer rates proposed by Furlani et al. (1999) were used in all treatments.

The nutrient solution was manually applied at a rate of twice the capacity of the pipes, considering the circulation frequency of the nutrient solution in each treatment, for homogenization and aeration inside the pipes. The replenishing of the nutrient solution lost by evapotranspiration in the tanks of each treatment was carried out every seven days; electrical conductivity and $\mathrm{pH}$ of the nutrient solution were monitored daily.

The hydroponic system used consisted of a waterproofed wooden support of $6 \mathrm{~m} \times 1.40 \mathrm{~m}$, with capacity for $126-\mathrm{m}$ long PVC pipes of $100 \mathrm{~mm}$ in diameter. Circular holes of $60 \mathrm{~mm}$ in diameter, equally spaced every $20 \mathrm{~cm}$ considering the central axis of each opening, were opened in these pipes (SANTOS JÚNIOR et al., 2016).

Rocket seeds (Eruca sativa L. cv. Folha Larga) were sowed in $180 \mathrm{ml}$ plastic cups, which were perforated in the sides and base, and filled with coconut fiber substrate; four seeds were sown per cup, the seedlings were irrigated daily (morning and 
afternoon) with public water up to 15 days after sowing (DAS), then, they were taken to the pipes according to previously established treatments.

The conditions inside the greenhouse were monitored daily and showed mean maximum temperature of $37.4^{\circ} \mathrm{C}$ and minimum of $32.2^{\circ} \mathrm{C}$; mean maximum relative humidity of $61.4 \%$ and minimum of $44.5 \%$; no phytosanitary problem was found regarding the rocket plants.

The biometric variables of the plants were evaluated at the end of the crop cycle (45 DAS), by measuring the plant height from the stem base to the top of the last leaf, using a ruler, and the root length from the stem base to the end of the longest root; and counting the number of photosynthetically active leaves with midrib larger than three centimeters.

Total fresh (TFW) and dry (TDW) weight, shoot fresh (SFW) and dry (SDW) weight, and root fresh (RFW) and dry (RDW) weight of the plants were measured in a precision balance. The plant parts were placed in a forced air circulation oven at $60^{\circ} \mathrm{C}$ until constant weight for measuring their dry weights. Then, the percentages of total (\%TDW), shoot $(\% \mathrm{SDW})$, and root $(\% \mathrm{RDW})$ dry weigh were calculated.

The results were subjected to normality test and analysis of variance using the $\mathrm{F}$ test. Treatments that presented significant interactions between the factors were subjected to statistical breakdowns. The means of the variables were compared by regression analysis regarding the salinity levels of the nutrient solution; and compared by the Tukey's test regarding the circulation frequencies of the nutrient solution. The analyzes were performed using the SISVAR program (FERREIRA, 2011) and a probability level of 0.05 .

\section{RESULTS AND DISCUSSION}

Table 1. Total (TFW), shoot (SFW), and root (RFW) fresh weights, and total (TDW), shoot (SDW), and root (RDW) dry weights of rocket plants (Eruca sativa L. cv. Folha Larga) subjected to salt stress and replenishing of the nutrient solution with the respective brackish water (BW), and with public water (PW).

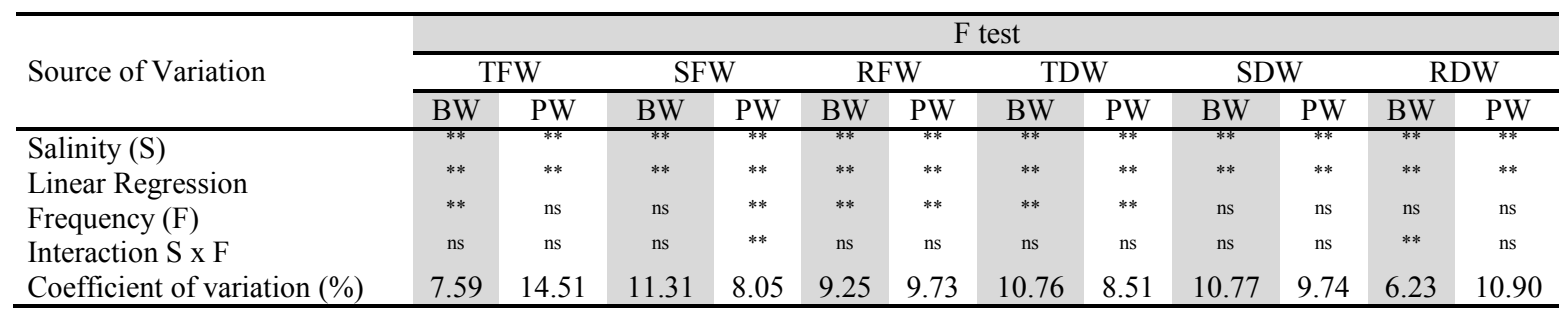

$* *=$ significant at 0.01 probability; $\mathrm{ns}=$ not significant. Data converted into $(\mathrm{x}+0.5)^{0.5}$

The data of TFW fitted to a linear model, with decreases of $2.5055 \mathrm{~g}$ per unit of ECs, and losses of up to $26.20 \%$ from the ECs of 1.5 to $9.0 \mathrm{dS}$ $\mathrm{m}^{-1}$, in Experiment I. Plants had $18.39 \%$ higher TFW $(p<0.05)$ when increasing the circulation
In Experiment I, the electric conductivity of the nutrient solution (ECs) increased in all saline

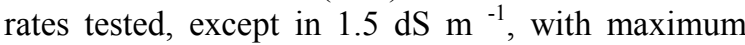
variations of $14 \%$ when using two, and $13.32 \%$ when using three circulations of the nutrient solution a day, with ECs of $9 \mathrm{dS} \mathrm{m}^{-1}$. However, this ECs represented the highest osmotic potential tested, with the lower water and nutrient uptake by the plants; and the greater accumulation of salts from the brackish water used in the replenishment. The variation of the $\mathrm{pH}$ of the nutrient solutions was lower than $15 \%$, regardless of the EC and circulation frequency of the nutrient solution.

In Experiment II, the use of public water for the replenishment of the nutrient solution reduced the salt concentrations and the ECs. The treatment with ECs of $1.5 \mathrm{dS} \mathrm{m}^{-1}$ had lower osmotic potential and probably higher water and nutrient absorption rates, therefore, it had the greatest decreases in ECs with two $(15.6 \%)$ and three $(14.4 \%)$ circulations of the nutrient solution per day. This removal/dilution of bases decreased the $\mathrm{pH}$ of the nutrient solution, which presented maximum variation of $20 \%$.

The EC and $\mathrm{pH}$ of the nutrient solutions were not adjusted to simulate field conditions, considering that the farmer does not make these adjustments. In general, no variations in the performance of the plants were found, except those typical of the salt stress.

The salinity of the nutrient solution affected significantly $(p>0.01)$ the total fresh (TFW) and dry (TDW) weight, shoot fresh (SFW) and dry (SDW) weight, and root fresh (RFW) and dry (RDW) weight of the plants, regardless of the salinity of the water used for replenish the nutrient solution. The circulation frequency of the nutrient solution affected significantly $(p<0.05)$ the TFW in Experiment I, the SFW in Experiment II, and the RFW and TDW in both experiments. The interaction between the factors affected the SFW in Experiment II, and the RDW in Experiment I (Table 1).

Rev. Caatinga, Mossoró, v. 31, n. 4, p. 1008 - 1016, out. - dez., 2018 
$\mathrm{m}^{-1}$ (Figure 1A). Souza Neta et al. (2013) evaluated the same rocket cultivar and found different results using water salinity range of 0.5 to $6.5 \mathrm{dS} \mathrm{m}^{-1}$, they found a quadratic behavior for TFW, with maximum values of $61.6 \mathrm{~g}$ for plants grown in coconut fiber,

A.

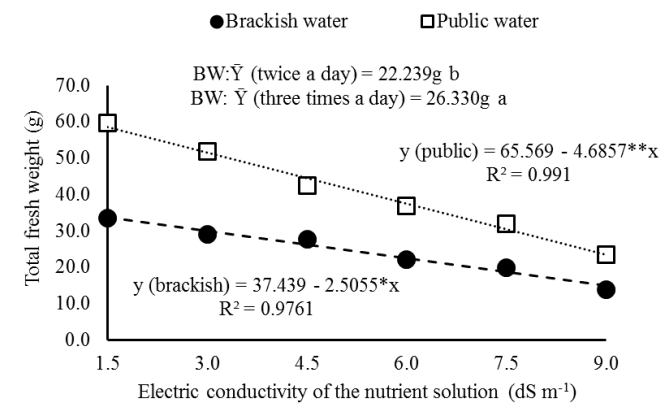

C.

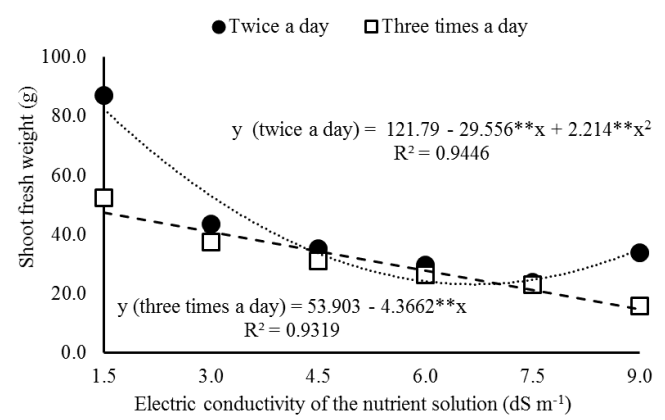

E.

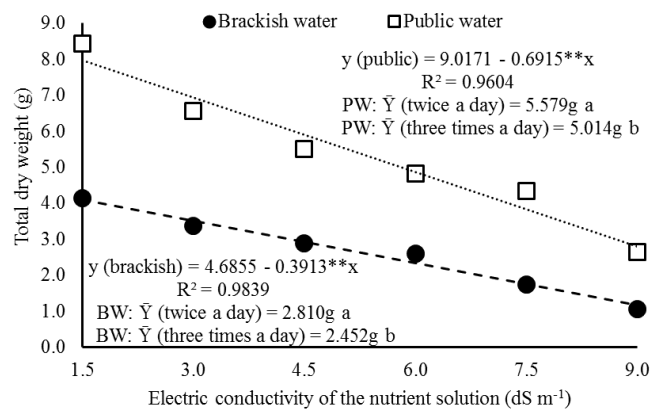

G.

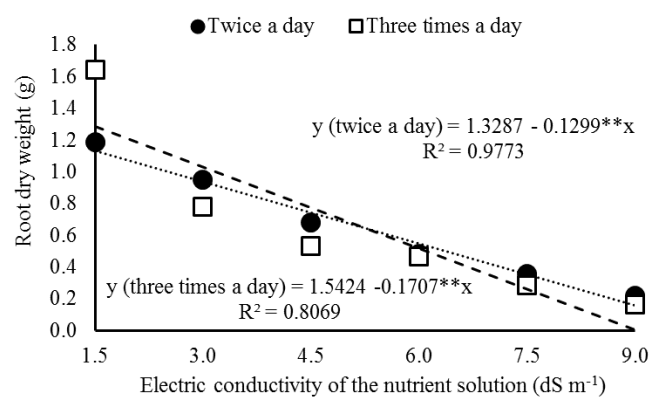

sand, and rice husks with ECs of $3.3 \mathrm{dS} \mathrm{m}^{-1}$. These differences may be due to the different nutrient solution cycling management (with and without nutrient cycling), since the TFW found for plants in this same ECs in Experiment II was $60.0 \mathrm{~g}$.

B.

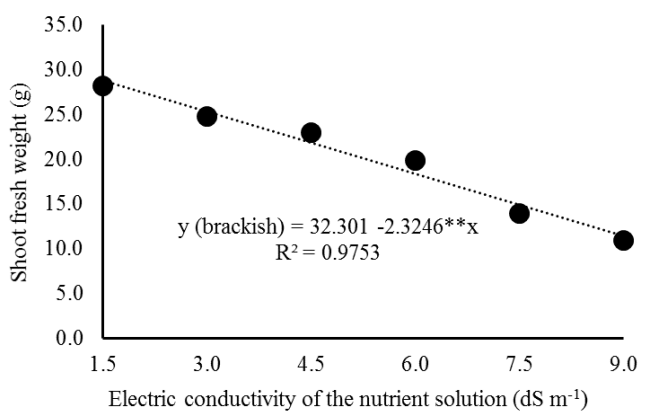

D.

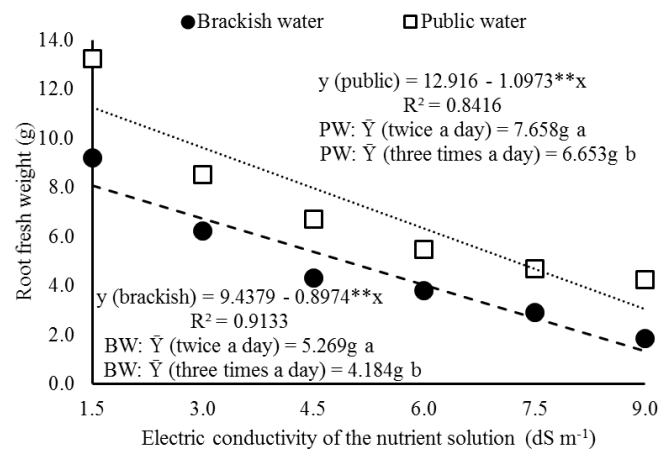

F.

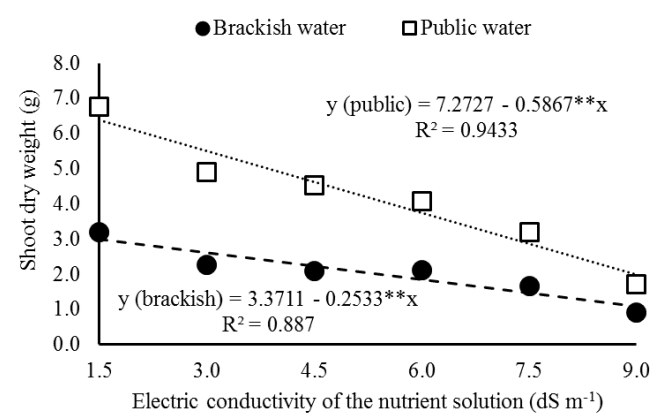

H.

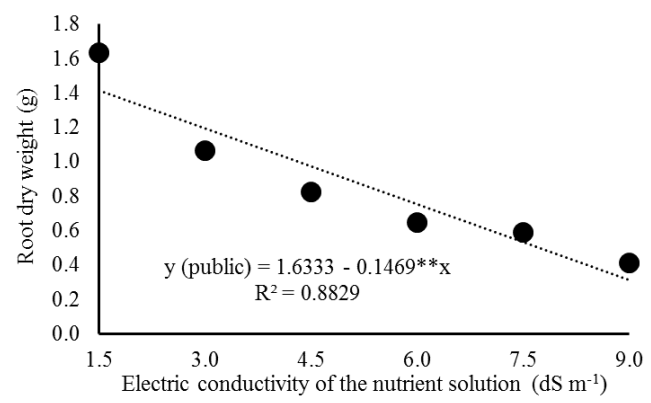

Figure 1. Total (A), shoot (B and C), and root (D) fresh weight, and total (E), shoot (F), and root (G and H) dry weight of rocket plants (Eruca sativa L. cv. Folha Larga) grown in saline nutrient solutions with different circulation frequencies and replenished with brackish, and public water. 
SFW presented a linear decrease of $2.3246 \mathrm{~g}$ per unit of ECs, with losses of up to $53.20 \%$ from the ECs of 1.5 to $9 \mathrm{dS} \mathrm{m}^{-1}$ in Experiment I (Figure 1B). The SFW decreased 4.3662 g per unit of ECs, with losses of up to $24.18 \%$ from the ECs of 1.5 to $9 \mathrm{dS} \mathrm{m}$ ${ }^{-1}$, in Experiment II when using three circulations of the solution a day. The data of SFW fitted to a quadratic model when using two circulations of the solution a day, with minimum of $23.149 \mathrm{~g}$ in the ECs

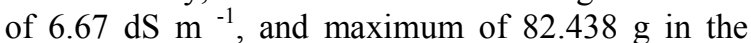
ECs of $1.5 \mathrm{dS} \mathrm{m}^{-1}$ (Figure 1C). Oliveira et al. (2012) evaluated rocket plants (Eruca sativa L. cv. Folha Larga) in field conditions and found a quadratic model for SFW in the salinity interval of 0.5 to $5 \mathrm{dS}$

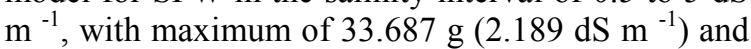
minimum of $17.1 \mathrm{~g}\left(5 \mathrm{dS} \mathrm{m}^{-1}\right)$.

RFW fitted to a decreasing linear model, with decreases of $0.8997 \mathrm{~g}$ per unit of ECs, and losses of up to $94.97 \%$ from the ECs of 1.5 to $9 \mathrm{dS} \mathrm{m}$ -1 in Experiment I. The use of brackish water with low circulation frequency of the nutrient solution caused a greater decrease in RFW (Figure 1D).

RFW decreased $1.0973 \mathrm{~g}$ per unit of ECs in Experiment II; the RFW of the plants grown in nutrient solution with ECs of $1.5 \mathrm{dS} \mathrm{m}^{-1}$ was 26.97fold that of plants grown in nutrient solution with ECs of $9 \mathrm{dS} \mathrm{m}^{-1}$. A lower RFW was found when a higher circulation frequency of the nutrient solution was used (Figure 2D), thus, the plants had a greater SFW development to the detriment of the RFW.

The TDW of the plants decreased $0.3913 \mathrm{~g}$ per unit of ECs, with losses of up to $52.16 \%$ from the ECs of 1.5 and $9 \mathrm{dS} \mathrm{m}^{-1}$ in Experiment I. However, the TDW was $11.26 \%$ higher when increasing the circulation frequency of the nutrient solution from two to three times a day (Figure 1E).
The TDW decreased $0.6915 \mathrm{~g}$ per unit of ECs, with losses of up to $86.64 \%$ from the ECs of 1.5 to $9 \mathrm{dS} \mathrm{m}^{-1}$ in Experiment II. Similar results of TDW were found by other authors (SILVA et al., 2008; SILVA et al., 2011), showing significant reductions in TDW with increasing salinity. The increase in circulation frequency of the nutrient solution from two to three times a day increased the TDW in $14.60 \%$ (Figure 1E).

The SDW decreased $0.2533 \mathrm{~g}$ per unit of ECs, with losses of up to $40.80 \%$ from the ECs of 1.5 to $9 \mathrm{dS} \mathrm{m}^{-1}$ in Experiment I. This decrease was $0.5867 \mathrm{~g}$ per unit of ECs, with losses of up to $20.84 \%$ in Experiment II (Figure 1F).

The RDW decreased $0.1299 \mathrm{~g}$ and $0.1707 \mathrm{~g}$ per unit of ECs when using circulation frequency of the nutrient solution of two and three times a day, respectively, in Experiment I. RDW had losses of up to $10.41 \%$ and $10.08 \%$ from the ECs of 1.5 to $9 \mathrm{dS}$ $\mathrm{m}^{-1}$ with circulation frequency of two and three times a day, respectively (Figure 2G). RDW decrease $0.1496 \mathrm{~g}$ per unit of ECs in Experiment II, with losses of up to $54.01 \%$ from the ECs of 1.5 to 9 $\mathrm{dS} \mathrm{m}^{-1}$ (Figure 1H).

The salinity of the nutrient solution affected $(p>0.01)$ the shoot $(\% \mathrm{SDW})$, and root $(\% \mathrm{RDW})$ dry weight percentages, plant height $(\mathrm{PH})$, number of leaves (NL) and root length (RL), regardless of the EC of the water used to replenish the nutrient solution. The circulation frequency of the nutrient solution affected significantly $(p<0.05)$ the \%TDW in Experiment I, the \%SDW in both experiments, and the \%RDW in Experiment II. The interaction between the factors affected significantly the \% TDW in Experiment II, and \% SDW and \%RDW in Experiment I (Table 2).

Table 2. Percentages of total (\%TDW), shoot (\%SDW) and root (\%RDW) dry weights, plant height (PH), number of leaves $(\mathrm{NL})$, and root length (RL) of rocket plants (Eruca sativa L. cv. Folha Larga) subjected to salt stress and replenishing of the nutrient solution with the respective brackish water (BW), and with public water (PW).

\begin{tabular}{|c|c|c|c|c|c|c|c|c|c|c|c|c|}
\hline \multirow{3}{*}{ Source of variation } & \multicolumn{10}{|c|}{ F test } & & \\
\hline & \multicolumn{2}{|c|}{$\% \mathrm{TDW}$} & \multicolumn{2}{|c|}{$\% \mathrm{SDW}$} & \multicolumn{2}{|c|}{$\%$ RDW } & \multicolumn{2}{|c|}{ PH } & \multicolumn{2}{|c|}{ NL } & \multicolumn{2}{|c|}{ RL } \\
\hline & BW & PW & BW & PW & BW & PW & BW & $\mathrm{PW}$ & BW & PW & BW & PW \\
\hline Salinity (S) & & $\mathrm{ns}$ & & & & & & & & & & \\
\hline Linear regression & ** & ns & ns & ns & $* *$ & ** & ** & ** & ** & ** & ** & $* *$ \\
\hline Quadratic regression & ns & ns & ns & ** & ns & ns & ns & ns & ns & ns & ns & ns \\
\hline Frequency $(\mathrm{F})$ & ** & ns & ** & $* *$ & $* *$ & ns & ns & ns & ns & ns & ns & ns \\
\hline Interaction $\mathrm{S} \times \mathrm{F}$ & ns & ** & ** & ns & ** & ns & ns & ns & ns & ns & ns & ns \\
\hline Coefficient of variation $(\%)$ & 14.77 & 9.67 & 8.64 & 12.04 & 7.98 & 7.73 & 8.35 & 11.92 & 6.79 & 7.47 & 7.03 & 5.93 \\
\hline
\end{tabular}

The $\% \mathrm{TDW}$ of plants in Experiment I reduced $0.5248 \%$ per unit of ECs, with losses of up to $44.57 \%$ from the ECs of 1.5 to $9 \mathrm{dS} \mathrm{m}^{-1}$. Increasing the frequency of circulation from two to three times a day increased the \%TDW in $39.42 \%$ (Figure 2A).

The data of \% TDW of plants in Experiment II fitted to a quadratic model when the circulation frequency of the nutrient solution was two times a day, with maximum of $15.1212 \%$ for the ECs of 3.36 $\mathrm{dS} \mathrm{m}^{-1}$. The increasing salinity had no significant effect on the \%TDW when the frequency was increased to three times a day, presenting a mean of $12.938 \%$ (Figure 2B). The biomass produced by the plant is related to photosynthesis and other processes that are affected by salinity. However, the use brackish water in the nutrient solution with replenishing with public water and circulation frequency of three times a day did not significantly affect the percentage of dry weight from the ECs of 1.5 to $9.0 \mathrm{dS} \mathrm{m}^{-1}$. 
A.

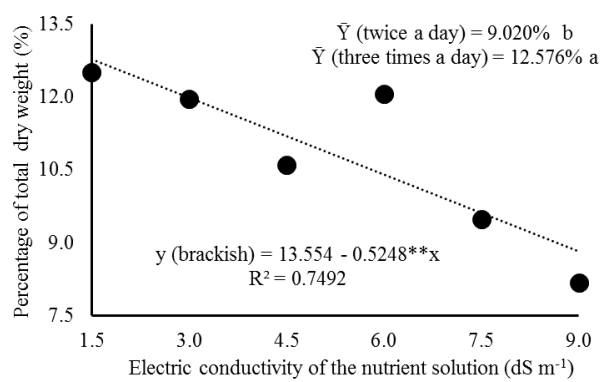

C.

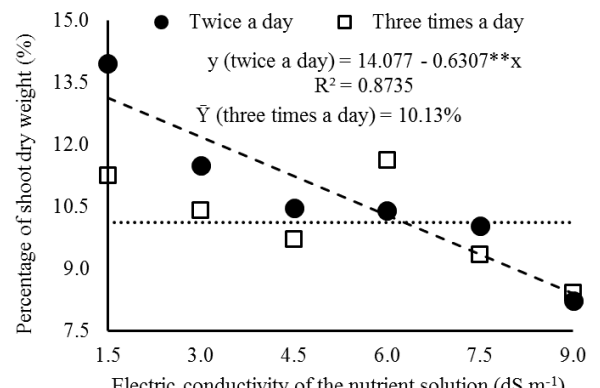

E.

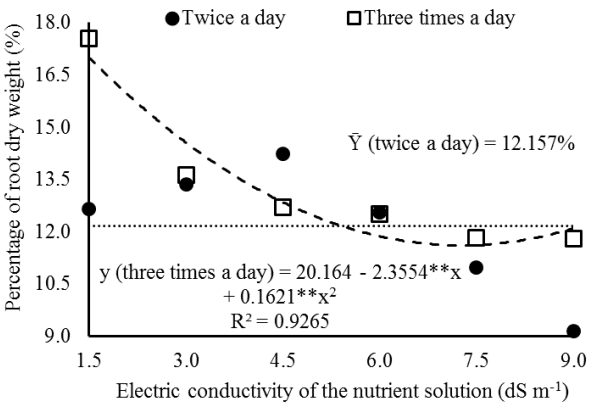

G.
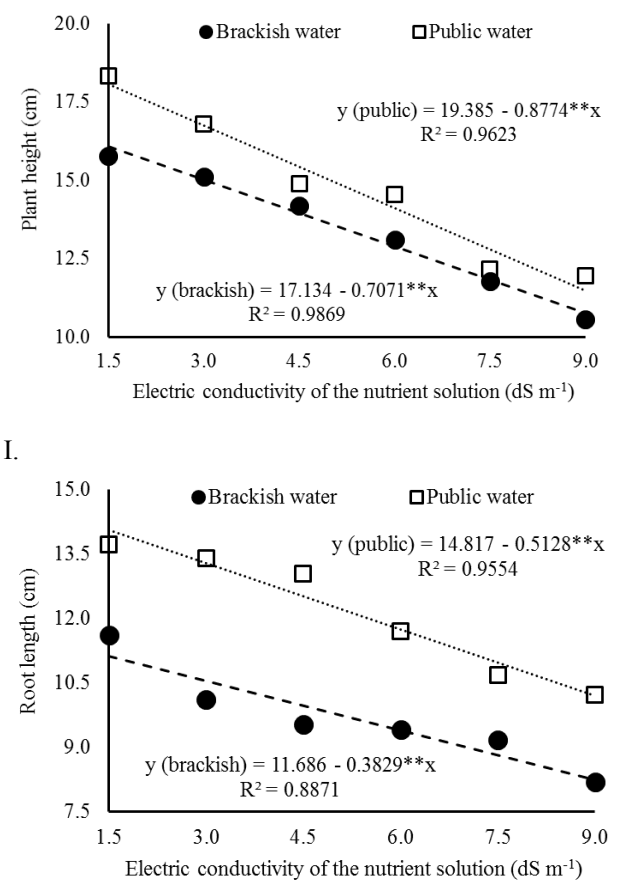

B.

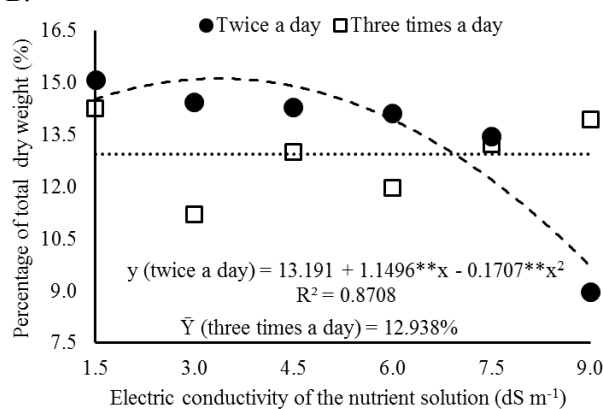

D.

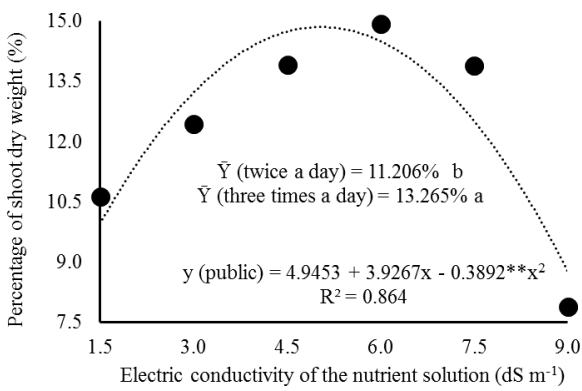

F.

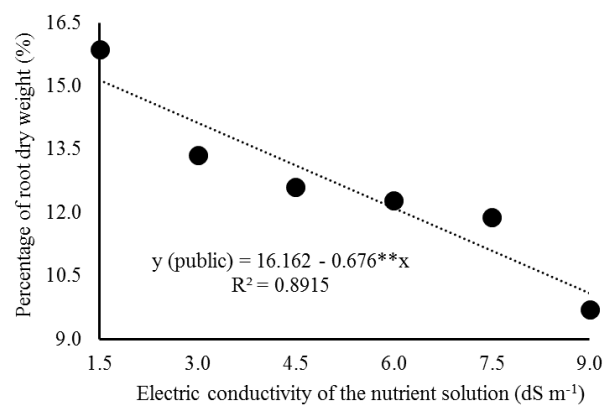

H.

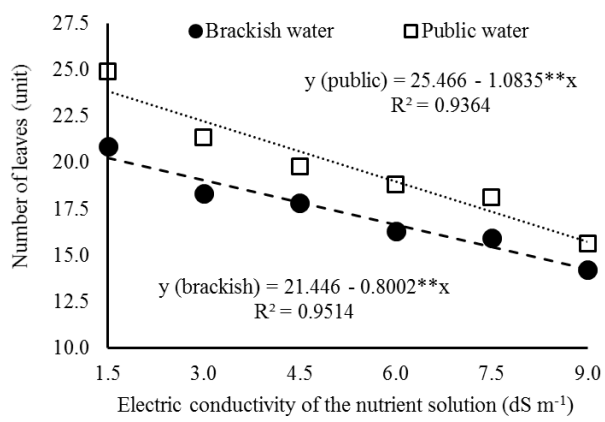

Figure 2. Percentage of total (A and B), shoot (C and D), and root (E and F) dry weights; plant height $(\mathrm{G})$, number of leaves $(\mathrm{H})$, and root length (I) of rocket plants (Eruca sativa L. cv. Folha Larga) subjected to salt stress and replenishing of the nutrient solution with the respective brackish water, and with public water, using two circulation frequencies for the nutrient solution. 
When using frequency of two circulations of the nutrient solution a day, the \% $\%$ DW of plants in Experiment I decreased $0.6307 \%$ per unit of ECs, with losses of up to $56.30 \%$ from the ECs of 1.5 to 9 $\mathrm{dS} \mathrm{m}^{-1}$. When using circulation frequency of three times a day, the salinity did not affect the \%SDW, which presented average of $10.13 \%$ (Figure 2C).

The data of \% SDW in Experiment II fitted to a quadratic model, with maximum of $14.8695 \%$ for the ECs of $5.04 \mathrm{dS} \mathrm{m}^{-1}$ (Figure 2D). The changes in the percentage of dry weight in the plant parts are consistent with salt stress problems, since increasing salinity decreases biomass production and alter the distribution of photoassimilates in the plant. According to Freitas et al. (2014), increasing salt concentration in the irrigation water hinders the distribution of photoassimilates to the plant shoot and root. Plants grown with circulation frequency of three times a day had $18.37 \%$ increase in $\% \mathrm{SDW}$ when compared to plants grown with circulation frequency of two times a day (Figure 2D).

The \%RDW of plants in Experiment I with circulation frequency of the nutrient solution of two times a day was not affected by the increases in ECs, presenting average of $12.157 \%$. When using circulation frequency of three times a day, the data of $\% \mathrm{RDW}$ fitted to a quadratic model with the minimum of $11.6077 \%$ for the ECs of $7.2 \mathrm{dS} \mathrm{m} \mathrm{m}^{-1}$ (Figure 3E). In Experiment II, the data of \%RDW fitted to a linear model, with decreases of $0.676 \%$ per unit of ECs, and losses of up to $50.30 \%$ from the ECs of 1.5 to $9 \mathrm{dS} \mathrm{m}^{-1}$ (Figure $2 \mathrm{~F}$ ).

The biometric aspects of plants in Experiments I and II were affected by the salinity of the nutrient solution, with decreases of 0.7071 and $0.8774 \mathrm{~cm}$ per unit of ECs in plant height $(\mathrm{PH})$, and losses of up to $49.24 \%$ and $57.28 \%$ from the ECs of 1.5 and $9 \mathrm{dS} \mathrm{m}^{-1}$, respectively (Figure 2G). Souza Neta et al. (2013) evaluated rocket plants (Eruca sativa L. cv. Folha Larga) under salt stress and found decreases of 0.75 and $0.666 \mathrm{~cm}$ per unit of ECs; however, in the Experiment II of the present work,

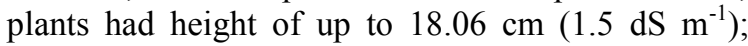
Souza Neta et al. (2013) found similar results, with up to $20.4 \mathrm{~cm}$ for the lowest ECs $\left(0.5 \mathrm{dS} \mathrm{m}^{-1}\right)$.

The data of NL of plants in Experiments I and II fitted to a linear model, with decreases of 0.8002 and 1.0883 leaves per unit of ECs, respectively (Figure 2H). The results found were consistent with those found by Souza Neta et al. (2013), but different from those found by Silva et al. (2011), who found no significant effect of salinity $\left(0.2\right.$ to $\left.5.2 \mathrm{dS} \mathrm{m}^{-1}\right)$ on the number of leaves of rocket plants. Despite these differences, in the present work, up to 23.84 leaves were found in plants grown in nutrient solution with ECs of $1.5 \mathrm{dS} \mathrm{m}^{-1}$ in Experiment II.

The root length (RL) of plants in Experiment I decreased $0.3829 \mathrm{~cm}$ per unit of ECs, with losses of up to $34.85 \%$. Similarly, the RL of plants in Experiment II decreased $0.5128 \mathrm{~cm}$ per unit of ECs, with losses of up to $37.69 \%$ (Figure 2I). The reductions in root growth found was probably due to the water stress caused by the increased salinity, which reduces the turgor pressure and results in a reduced cellular expansion, causing negative effects in the metabolism, growth, and establishment of the plants (JALEEL et al., 2009).

\section{CONCLUSION}

Increasing electrical conductivity of the nutrient solution used for the growth of rocket plants (Eruca sativa L. cv. Folha Larga) in hydroponic system reduces their biomass production, percentage of dry weight, and growth.

Replenishing the nutrient solutions lost by evapotranspiration with public water $\left(0.12 \mathrm{dS} \mathrm{m}^{-1}\right)$ results in lower losses in biomass production, and plant growth.

Increasing frequency of circulation of the nutrient solution does not affect the growth of rocket plants, however, a higher circulation frequency makes the plant to prioritize the shoot biomass accumulation to the detriment of the root.

\section{ACKNOWLEDGMENTS}

The authors thank the National Council for Scientific and Technological Development (CNPq) for the project financing.

\section{REFERENCES}

COSTA, C. M. F. et al. Desempenho de cultivares de rúcula sob telas de sombreamento e campo aberto. Semina: Ciências Agrárias, Londrina, v. 32, n. 1, p. 93-102, 2011.

FERREIRA, D. F. Sisvar: a computer statistical analysis system. Ciência \& Agrotecnologia, Lavras, v. 35 , n. 6 , p. 1039-1042, 2011.

FREITAS, M. A. C. et al. Crescimento e tolerância à salinidade em três espécies medicinais do gênero Plectranthus expostas a diferentes níveis de radiação. Revista Brasileira de Plantas Medicinais, Campinas, v. 16, n. 4, p. 839-849, 2014.

FURLANI, P. R. et al. Nutrição Mineral De Plantas, Preparo E Manejo De Soluções Nutritivas. Informe Agropecuário, Belo Horizonte, v. 20, n. 200/201, p. 90-98, 1999.

JALEEL, C. A. et al. Drought stress in plants: a review on morphological characteristics and 
pigments composition. International Journal of Agriculture Biology, Faisalabad, v. 11, n. 1, p. 100$105,2009$.

LEITE, D. et al. Viabilidade econômica da implantação do sistema hidropônico para alface com recursos do PRONAF em Matão-SP. Revista IPecege, Piracicaba, v. 2, n. 1, p. 57-65, 2016.

LIMA, G. S. et al. Respostas morfofisiológicas da mamoneira, em função da salinidade da água de irrigação e adubação nitrogenada. Revista Irriga, Botucatu, v. 19, n. 1, p. 130-136, 2014.

LIMA, L. A. et al. Tolerância da berinjela à salinidade da água de irrigação. Revista Agro@mbiente On-line, Boa Vista, v. 9, n. 1, p. 2734, 2015.

MENEGAES, J. F. et al. Produção sustentável de alimentos em cultivo hidropônico. Revista Monografias Ambientais, Santa Maria, v. 14, n. 3, p. 102-108, 2015.

NASCIMENTO, I. B. et al. Desenvolvimento inicial da cultura do pimentão influenciado pela salinidade da água de irrigação em dois tipos de solos. Agropecuária Científica no Semiárido, Patos, v. 11, n. 1, p. 37-43, 2015.

NUNES, R. L. C. et al. Efeitos da salinidade da solução nutritiva na produção de pimentão cultivado em substrato de fibra de coco. Revista Caatinga, Mossoró, v. 26, n. 4, p. 48-53, 2013.

OLIVEIRA, F. A. et al. Desempenho de cultivares de rúcula sob diferentes níveis de salinidade da água de irrigação. Agropecuária Científica no Semiárido, Patos, v. 8, n. 3, p. 67-73, 2012.

PANTOJA NETO, R. A. et al. Viabilidade econômica da produção de hortaliças em sistema hidropônico em Cametá-PA. Revista Brasileira de Agropecuária Sustentável, Viçosa, v. 6, n. 2, p. 75 $80,2016$.

RICHARDS, L. A. Diagnosis and improvement of saline and alkali soils. 1. ed. Washington: United States Salinity Laboratory, 1954. 160 p. (Agriculture Handbook, 60).

SANTOS JÚNIOR, J. A. et al. Crescimento do girassol em sistema semi-hidropônico sob estresse salino e densidades de plantio. Revista Irriga, Botucatu, v. 20, n. 2, p. 233-247, 2015.

SANTOS JÚNIOR, J. A. et al. Produção e póscolheita de flores de girassóis sob estresse salino em hidroponia de baixo custo. Engenharia Agrícola, Jaboticabal, v. 36, n. 3, p. 420-432, 2016.
SANTOS JÚNIOR, J. A. et al. Substratos e tempo de renovação da água residuária no crescimento do girassol ornamental em sistema semi-hidroponia. Revista Brasileira de Engenharia Agrícolca e Ambiental, Campina Grande, v. 18, n. 8, p. 790797,2014

SANTOS, A. N. et al. Cultivo hidropônico de alface com água salobra subterrânea e rejeito da dessalinização em Ibimirim, PE. Revista Brasileira de Engenharia Agrícola e Ambiental, Campina Grande, v. 14, n. 9, p. 961-969, 2010.

SANTOS, R. S. S. et al. Uso de águas salobras na produção de rúcula cultivada em substrato de fibra de coco. Revista Caatinga, Mossoró, v. 25, n. 1, p. 113-118, 2012.

SANTOS, S. T. et al. Qualidade de mudas de cultivares de tomateiro em função de soluções nutritivas de concentrações crescentes. Revista Agro@mbiente On-line, Boa Vista, v. 10, n. 4, p. 326-333, 2016.

SILVA, A. O. et al. Consumo hídrico da rúcula em cultivo hidropônico NFT utilizando rejeitos de dessalinizador em Ibimirim-PE. Revista Irriga, Botucatu, v. 17, n. 1, p. 114-125, 2012.

SILVA, A. O. et al. Produção de rúcula em sistema hidropônico NFT utilizando água salina do Semiárido - PE e rejeito de dessalinizador. Revista Brasileira de Ciências Agrárias, Recife, v. 6, n. 1, p. 147-155, 2011.

SILVA, F. V. et al. Cultivo hidropônico de rúcula utilizando solução nutritiva salina. Revista Brasileira de Ciências Agrárias, Recife, v. 8, n. 3, p. 476-482, 2013.

SILVA, J. K. M. et al. Efeito da salinidade e adubos orgânicos no desenvolvimento da rúcula. Revista Caatinga, Mossoró, v. 21, n. 5, p. 30-35, 2008.

SILVA, J. L.; SILVA, E. S. B.; KOLLESKA, L. Respostas produtivas de cultivares de rúcula em sistema hidropônico. Revista Ciências Exatas e da Terra e Ciências Agrárias, Campo Mourão, v. 11, n. 1, p. 16-24, 2016.

SILVA, M. G. et al. Crescimento e produção de coentro hidropônico sob diferentes densidades de semeadura e diâmetros dos canais de cultivo. Revista Irriga, Botucatu, v. 21, n. 2, p. 312-326, 2016.

SOARES, T. M. et al. Combinação de águas doce e salobra para produção de alface hidropônica. Revista Brasileira de Engenharia Agrícola e Ambiental, Campina Grande, v. 14, n. 7, p. 705-714, 2010. 
SOUZA NETA, M. L. et al. Efeitos da salinidade sobre o desenvolvimento de rúcula cultivada em diferentes substratos hidropônicos. Revista Agro@mbiente On-line, Boa Vista, v. 7, n. 2, p. 154-161, 2013. 